Journal of Education and Vocational Research (ISSN 2221-2590)

Vol. 6, No. 4, pp. 31-37, December 2015

\title{
Effect of Industrial Work Practice and Family Environment on Interest in Entrepreneurship to Students of Vocational High School
}

\author{
Muhammad Rakib \\ State University of Makassar, Indonesia \\ rakib_feunm@yahoo.com
}

\begin{abstract}
The purpose of this study was to determine the effect of industrial work practices and family environment on interest in entrepreneurship at state vocational high school 1 of Parepare. Population showed in this study was all students of class XII at state vocational high school 1 of Parepare in the academic year 2015/2016 as many as 232 students. The total sample of $30 \%$ or as many as 70 students. Data collection techniques in this study are a questionnaire, observation, interviews, and documents. The data analysis techniques used in this study is multiple regression analysis using the Statistical Product and Service Solutions (SPSS). The results showed that (1) the industrial work practices has a positive and significant impact on interest in entrepreneurship at students of vocational high school of state 1 of Parepare by 58.40 $\%$, (2) family environment has a positive and significant impact on interest in entrepreneurship on students of vocational high school of state 1 of Parepare by 55.70\%, and (3) influences of industrial work practices and family environment simultaneously positive and significant impact on students of vocational high school of state 1 of Parepare by $65.30 \%$. The study recommended that the head school should more pay attention to the implementation of the industrial work practices, so that students' interests in entrepreneurship can be improved estuary on improving the quality of education
\end{abstract}

Keywords: Industrial Work Practice, Family Environment, Entrepreneurship Interest

\section{Introduction}

In the law of Republic of Indonesia No. 20 of 2003 on National Education System in article described 15 that "Vocational education is an education that prepares students to work in a particular field". Furthermore, the Government Regulation No. 29 of 1990 in article 3 paragraphs (2) states that "vocational secondary education priority to preparing students to enter the workforce and develop a professional attitude". Vocational high school (SMK) is expected to develop students' interest in entrepreneurship and after graduation of vocational school is not only looking for work but capable of independent and can create their own jobs. Therefore, one of the programs implemented by SMK to achieve this is through the working practices of the industry. Implementation of the working practices of the industry will indirectly give students experience and sufficient knowledge and skills in the work because in addition to learning how to get a job, are also taught how to have jobs that are relevant to their talents and the ability to work independently. Thus, experience, knowledge, and skills acquired by students who have followed the practice of industrial employment are expected to increase the interest of students to entrepreneurship. In addition to the working practices of the industry, the family environment is also very important in growing interest in entrepreneurship for students. Family environment is a home base for every human life. Family education is part of the overall education system. The family had a very strong influence on the development of the child's personality, because most of the child's life was in the midst of his family. Both parents have a very important role in realizing the child's personality.

Given that education entrepreneurship is lifelong, so it is a period of parental education for children regardless of age, parents are not only in charge of caring for the child but also has the task of laying the foundations of education, religious feeling, volition, a sense of joy in beauty, prowess in economics, knowledge, ideas and other social attitudes. Therefore, the maximum support of parents who will form the entrepreneurial spirit for children. Vocational high school in addition to conducting learning programs that support entrepreneurial interest also seeks to involve parents in the hope of encouraging students to cultivate interest in entrepreneurship. This is done through school committees are always in collaboration with the school to discuss the development and socialization of school and student work programs involving 
school students or children. Thus, parents will understand the orientation of the schools that eventually expected to provide a boost to their children to develop an interest in entrepreneurship. Knowledge, attitudes, and skills and encouragement of parents to foster interest in entrepreneurship for students. Interest in entrepreneurship will make a person to be more active search for and take advantage of business opportunities to optimize its potential. Interests whom are not under the birth but grow and develop in accordance with the factors that influences it.

Vocational high school is a formal educational institution that is expected to create output that is ready to face the world of work. Vocational high school should be able to do good management, especially in the implementation of learning that can support the interest in entrepreneurship for students. Moreover, it also should be able to create a conducive learning atmosphere in the form of practical learning program that supports the industry working interest in entrepreneurship for students, as well as the expected contribution of the family by involving parents in supporting the learning process that supports students' interest in entrepreneurship. Based on the background of the problem, it can be argued formulation of the problem is: "Is the practice of industrial employment and family environment has an influence on students' interest in entrepreneurship at vocational high school of state 1 of Parepare? The purpose of this study was to determine the effect of industrial working practices and family environment on student interest in entrepreneurship at vocational high school of state 1 of Parepare. As Hilgard and Bowers (2004: 22) defines interest as "a persisting tendency to pay attention to and enjoy some activity or content, especially a vocational interest". Interest in entrepreneurship is not inborn but grows and develops in accordance with the factors that influence. Factors influencing the decision to entrepreneurship growth are a result of interaction of several factors: the character of a person's personality and environment (Bygrave, 2003). As Lambing and Kuehl (2007), new research suggests there are four things that influence the decision to entrepreneurship, namely personal, cultural environment, social conditions, and the combination of the three. Meanwhile, according to Hisrich (2005: 18) and Alma (2011: 12), factors that affect interest in entrepreneurship is an educational environment, a person's personality and family environment.

So, the interest in entrepreneurship is influenced by several factors, including the self, an environmental culture, social conditions, and others. The industrial work practice is a form of education provision of professional expertise, which combines in a systematic and synchronized between education programs in schools and exploitation program obtained through working directly in the work to achieve a level of professional expertise. Where such as professional expertise can only be established through three main elements, namely science, techniques and tips. Science and techniques can be learned and mastered when and wherever we are, while the issue cannot be taught but can be controlled through the process of doing direct to work on the field of the profession itself. The industrial work practices implemented to meet the man power needs of professionals in the art. Through the practice of industrial employment is expected to create the professional workforce. Where students who carry out such education is expected to apply the knowledge acquired and simultaneously studying the industrial world. Without holding this industrial work practices students cannot be directly plunge into the world of industry because students do not know the situation and working conditions. In addition, the company cannot know where the professional labor where labor and unprofessional. Dual system of education had to be implemented because it can be beneficial to all parties who carry it out.

Implementation industrial practice work aims to: produce a workforce that has the professional expertise (with the level of knowledge, skills, and work ethic in accordance with the demands of employment), strengthening "link and match" between school and the world of work, improve the efficiency of the process of education and training professional-quality workforce and give recognition and appreciation of the work experience as part of the educational process. Activities of the working practices of the industry are a mandatory program to be implemented by the school, especially vocational and followed by learners. Education Minister's decision No. 086/U/1993/ chapter IV clause C1. The purpose of the activities of the cult of the industrial work itself according to the Directorate of Technical and Vocational Education (Dikmenjur, 2008) are: (1) Produce workers who have professional expertise, the workforce has the level of knowledge, skills, and work ethic in accordance with the demands of the field-work. (2) Improve and strengthen linkages and equivalence (link and match) between educational institutions of vocational training and the world of work. (3) Improving the efficiency of the education process and training of qualified and professional 
workforce. (4) Giving recognition and appreciation of work experience as a process of teaching. As Uya that, field-work Practice goals are: (1) In order for the student to add insight to the way down to study abroad in the world of industry, (2) order for students to know how to work in the industrial world that emphasizes discipline, safety and quality of products, (3) To supplement the teaching curriculum of vocational high school, (4) Produce a quality workforce, that workforce has the level of knowledge, skills, work ethic in accordance with the demands of the field-work, (5) Strengthening the link and match between the vocational and the world of work, and (6) Improve the effectiveness and efficiency of the education process and training of qualified labor.

Family environment is one of the environmental factors that can affect a person's interest in entrepreneurship. The factors contained in the family according to Slameto (2003:60-64) family environment consisting of: (1) How to educate parents, (2) Relation between family members, (3) The atmosphere of the house, (4) family economic situation (5) Definition of Parents, (6) Background Culture. As Supartono (2004:50) says that the way parents in achieving success in a job is a good capital to train their interests, skills and ability of certain values related to the work desired child. The family factors as determinants of student success consist of: (1) Economic family conditions and (2) the emotional relationship of parents and children, (3) How to educate parents (Sobur, 2003:248-249). There are several previous studies which are relevant to this study include research Putra (2009), entitled "Effect of industrial work practices to the interest in entrepreneurship in class XII in Automotive Engineering Program at vocational high school of Texmaco of Pemalang". These results indicate that there is significant influence between work practices of the industry interest in entrepreneurship in vocational students of Texmaco. With the industry work practices program, will give impetus to the student interest in entrepreneurship. Research conducted by Yulianto (2013) with the title "Achievement Effects of Industrial Employment Practices against the Interests of Entrepreneurship Student" indicates that there is a positive effect of industrial work practices to variable interest in entrepreneurship. Yulianto study concluded that the hypothesis "There is the influence of the achievements of the industry working practices interest in entrepreneurship students majoring in mechanical engineering automotive class XII of Integrated SMK of Darul Ulum of Jepara" unacceptable.

As Ditya (2011) conducted a study entitled "Factors affecting the interest in entrepreneurship students at the University of Education of Indonesia "The results showed that the variables of the family environment, the mental attitude to entrepreneurship students, and students' perceptions of entrepreneurship has a positive influence on interest in entrepreneurship students at the University of Education of Indonesia. In the study Guntoro (1997) mentions the existence of a high interest is also not free from the activities of the working practices of the industry. The study concluded that there is a relationship with the achievement of the industrial work practices with interest students in entrepreneurship class II of vocational high school of Yapin of Bekasi in academic year 2006/2007. It is concluded that the higher the value of industrial work practices followed by the high interest of the students for self-employment. Furthermore, research conducted by Yanti et al. (2014) with the title "The Influence of Family Environment for Entrepreneurship Interests of students class XI of vocational high school of state 1 of Singaraja" which aims to determine the influence of family environment on student interest in entrepreneurship. Research results indicate that the student's family environment is very high with a total score of 5998, a very high interest in entrepreneurship students with a total score of 7808, and the family environment and significant positive effect on students' interest in entrepreneurship with a percentage of $18.3 \%$ and $81.7 \%$ influenced other factors. Based on these results, we can conclude that industrial work practices and family environment are all factors that can influence the interest in entrepreneurship.

\section{Methodology}

This study was classified as a quantitative descriptive research. Population showed in this study was all students of class XII at vocational high school of state 1 of Parepare the academic year 2015/2016 as many as 232 students. The total sample of $30 \%$ or as much as 70 respondents. Data collection techniques in this study are a questionnaire, observation, interviews, and documents. The data analysis techniques used in this study is multiple regression analysis using the Statistical Product and Service Solutions (SPSS). 


\section{Results and Discussion}

Influence of Industrial Work Practices for Entrepreneurship Interests.

The results showed that the $\mathrm{R}$ value of 0.764 and $\mathrm{R}$ Square of 0.584 . This means that the Job Training Industry has a positive influence on interest in entrepreneurship, with strong category and the contribution of Industrial Work Practices for Student Interest in Entrepreneurship at vocational high school of state 1 of Parepare by $58.40 \%$ or $41.60 \%$ while the rest is determined by other factors. In this study also obtained the value of Sig.000a, this means the influence of the Job Training Industry Student Interest in Entrepreneurship at vocational high school of state 1 of Parepare is very significant, which significantly limits the value obtained is less than the value significantly limit of 0.05 . Thus, the research hypothesis which states that "there are significant Industrial Work Practices significant interest in Entrepreneurship to students of vocational high school of state 1 of Parepare accepted. "As for the influence of Industrial Work Practices for Entrepreneurship interest is determined by the linear equation $Y=14.296+1,134 \mathrm{X} 1$. This means that every increase of one in the variable Industrial Work Practices will increase by 1,134 in the variable interest on Entrepreneurship of students of vocational high school of state 1 Parepare. The research result is in line with the results Guntoro (1997) and Yulianto (2013) that there is a positive effect of industrial work practices to variable interest in entrepreneurship. The head school is the leader of education has an important role in developing their education agency. Nowadays, science and technology education has enormous influence, because education is always changing in accordance with the demands of society and the life of the State concerned. To deal with this, the head school is required to improve the performance of teachers in order to trust the public has not changed, so that it can generate a good fit with the times. In order to achieve a good quality of education, one way in which the head school is through increased interest in entrepreneurship, because teachers will be the most important element in determining the success or failure of education. A head school as educational leaders and authorities has an important task in print professional teacher then in this case the head school must have the vision, mission and strategy in bringing the students towards the achievement of a more optimal and able to bring the students in achieving a better performance.

Interest in entrepreneurship that is expected to boost the quality and relevance of education, in its implementation depends on many factors that influence and interrelated, such as factors working practices of the industry. Industrial Work Practices to determine the quality, without good industrial practice quality improvement process cannot be done and realized (Sallis, 2006: 170). Industrial Work Practices primacy effect is not merely a form of instruction, but rather the motivations or triggers that can provide inspiration to the students, so that the initiative and creativity to develop optimally to increase interest in entrepreneurship. Based on the results of the study showed that the Industrial Work Practices affect the interest in entrepreneurship in the context of research carried out to show the truth scientifically. Industrial Work Practices is a very big influence on the achievement of the goals of the school, especially the purpose improve the quality and interest in entrepreneurship, cooperation of school and the world of business or industry in order to improve the quality will get good success if the program can generate and increase interest in entrepreneurship to meet the needs and personal satisfaction as well as the goals and targets of school. Based on these descriptions can be presumed that there are significant Industrial Work Practices for Student Interest in Entrepreneurship at vocational high school of state 1 of Parepare. In other words, the better the Industrial Work Practices increasingly better the interests of Entrepreneurship.

Influence of Family Environment for Entrepreneurship Interests: The results showed that the R value of 0.746 and $\mathrm{R}$ Square of 0.557 . This means that family environment has a positive influence on the strong interest in entrepreneurship by category and size of the contribution to the Interests of Family Environment on Student Entrepreneurship of vocational high school of state 1 of Parepare by $55.70 \%$ or $44.30 \%$ while the rest is determined by other factors. In addition, the results of this study also showed that the value of Sig.L000a is less than the significance limit of 0.05 . This means that the influence of family environment on the interest in entrepreneurship in students of vocational high school of state 1 of Parepare is very significant. Entrepreneurship of students. Thus, the research hypothesis which states that "there is the influence of family environment in a positive and significant impact on student interest in entrepreneurship at vocational high school of state 1 of Parepare accepted. As for the size of the contribution to the Family Environment variable interest demonstrated entrepreneurship through that line is the linear equation $Y=29.175+0,884 \mathrm{X} 2$, This 
means that every increase of one in the Family Environment variables, will increase by 0.884 at variable interest Entrepreneurship. The family environment plays an important role in increasing interest in entrepreneurship. The family environment is an important thing that should be improved for a family because it will affect the interest in entrepreneurship. Because, the better the Environment family of a student, the higher the interest This is consistent with the results of research conducted by Ditya (2011) and Yanti, et al. (2014), a family environment and a significant positive effect on students' interest in entrepreneurship. Thus, a student needs to maintain and preserve the family environment in order to establish good communication and harmony with all the components of society. Given a good family environment that is owned by a student will be able to increase the motivation and interest in entrepreneurship.

Interest in entrepreneurship refers to a situation where students in a school are sincerely doing things that are associated with learning activities at school. Seriousness of learning is evident in trying to resolve all the duties and charges in each subject well, organized, disciplined enter the classroom to follow the subject matter and the guidance of learning activities, exams orderly/ regular and loyal and obedient run or completing other school activities right time. Thus, interest in entrepreneurship is the result of learned and accomplished by a teacher in an educational institution in accordance with the duties and responsibilities in achieving the educational goals outlined. Implementation of the education indirectly raise the awareness of education in improving the family environment manifested in Family Environment dimension, namely how parents educate, parents relationship, home atmosphere, and economic circumstances. The condition of the family environment would also be an impact on student success in managing the interaction between students and students or between students and other environments, so that a student can maintain order and control the classroom, participating in learning activities, and improve academic achievement.

Influence of Industrial Work Practices and Family Environment on Interests in Entrepreneurship: These results indicate that the $\mathrm{R}$ value of 0.808 and $\mathrm{R}$ Square of 0.653 . This means Industrial Work Practice and Family Environment simultaneously have a positive influence on the interest of Entrepreneurship with a very strong category, and the contribution of Industrial Work Practices and Environmental Family Interests simultaneously towards entrepreneurship by $65.30 \%$ or $44.70 \%$ while the rest is determined by other factors. In addition, the results of this study also showed that the value of Sig.000 a is smaller than the value significantly limit is 0.05 , this means that the influence of Industrial Work Practices and Family Environmental on Interests simultaneously towards entrepreneurship in students of vocational high school of state 1 of Parepare is very significant. Thus, the research hypothesis which states that "there are significant Industrial Work Practices and Family Environmental simultaneous positive and significant for the Student Entrepreneurship Interest of vocational high school of state 1 of Parepare is received." As for the contribution of Industrial Work Practice and Family Environment on Interests simultaneously towards entrepreneurship in students of vocational high school of state 1 of Parepare decided in the form of the line equation is $\mathrm{Y}=$ $9.592+0,694 \mathrm{X} 1+0,470 \mathrm{X} 2$. This means that every increase of one in the variable Industrial Work Practices and Family Environment will increase by 1,164 in the variable interest in Entrepreneurship of students of vocational high school of state 1 of Parepare. Generally Interests Entrepreneurship seen from the desire, motivation, and business opportunities are good.

Many factors affect the interests of Entrepreneurship usual good factor of the student as well as outside factors the student or perhaps because both these factors simultaneously. In this study the factors that affect interest in entrepreneurship which is the focus of the study authors is a factor Industrial Work Practices and Family Environment factors. The Industrial Work Practices can affect Interests in entrepreneurship. Knowledge, discipline, loyalty, and courage students can level through a program of industrial work practices that will increase students' interest in entrepreneurship, if the implementation of the program industry practice goes well according to the program has been formulated in the curriculum it will affect students' interest in entrepreneurship. In addition, Family Environment also is a matter that affects the interest in entrepreneurship which have a high score, ranking first will not necessarily be successful in the job, whereas people who are outstanding in performance but even more unusual success in employment this is caused by emotional factors obtained from the family environment such as how parents educate, parents relationship, home atmosphere, and economic circumstances. If a student is able to control emotions then he will be able 
to respond to what was assigned to him by the leadership well and he will try to focus on the work assigned to him as quickly as possible so that their work will be good.

\section{Conclusion and Recommendations}

Based on the results of research and discussion, it put forward some conclusions, namely:

- Work Practices Industry has a positive and significant impact on interest in entrepreneurship to students of vocational high school of state 1 of Parepare by $58.40 \%$ with the linear equation $\mathrm{Y}=$ $14.296+1,134 \mathrm{X} 1$ that any increase in the variable practice of the industry, will increase by 1,134 in the variable interest in entrepreneurship of students of vocational high school of state 1 of Parepare.

- Environment Family has a positive and significant impact on interest in entrepreneurship of students of vocational high school of state 1 of Parepare by 55.70\% with a line equation Y $=29195+0,884$ X2, namely every increase of one in the family environment variables, will increase by 0.884 in the variable interest in Entrepreneurship of students of vocational high school of state 1 of Parepare.

- The influences of Industrial Work Practices and Family Environment simultaneously positive and significant impact on interest in entrepreneurship to students of vocational 1 Parepare by $65.30 \%$ with a line equation $\mathrm{Y}=9.592+0,694 \mathrm{X} 1+0,470 \mathrm{X} 2$ that every increase of one in the variable Industrial Work Practices and Family Environmental, will increase by 1,164 in the variable interest in Entrepreneurship of students of vocational high school of state 1 of Parepare.

Suggestions: Based on the conclusions of this study, may put forward suggestions as follows:

- To the head school, should pay more attention to the implementation of industrial work practice on interest in entrepreneurship so that students can be further improved the estuary at improving the quality of education, especially vocational high school of state 1 of Parepare.

- To the students, should follow the program with good industry practice and increasing interest in entrepreneurship that can be independent or create jobs after completion of their education program.

- Researchers should the results of this study can be used as a reference in order to assess the field of education management that is relevant, especially regarding the industrial work practice, family environment, and interest in entrepreneurship.

\section{References}

Alma, B. (2011). Kewirausahaan Untuk Mahasiswa dan Umum. Bandung: Alfabeta.

Bygrave, W. D. (2003). The Portable MBA Entrepreneurship. Jakarta: Binarupa Aksara.

Dikmenjur. (2008). Kurikulum SMK. Jakarta: Dikmenjur.

Ditya, G. (2011). Faktor-faktor yang Mempengaruhi Minat Berwirausaha Mahasiswa Universitas Pendidikan Indonesia. Portal Jurnal, 6(1).

Guntoro, H. (1997). Hubungan Prestasi Kerja Praktik Industri Terhadap Minat Berwirausaha Siswa Kelas II Teknik Otomotif SMK Yapin Bekasi Tahun Ajaran 2006/2007. Semarang: UNES.

Hilgard, E. R. \& Bowers, G. (2004). Theory of Learning: Century Psychology Series. New York: National Book Foundation.

Hisrich, R. D. (2008). Entrepreneurship, Edisi 7. Jakarta: Salemba Empat.

Lambing, P. \& Kuehl, C. R. (2007). Entrepreneurship. 4th edition. Upper Saddle River: Prentice Hall.

Peraturan Pemerintah Republik Indonesia Nomor 29 Tahun 1990 tentang Pendidikan Menengah. Jakarta: Departemen Pendidikan dan Kebudayaan.

Putra, I. A. (2009). Pengaruh Pengalaman Praktik Kerja Industri terhadap Minat Berwirausaha pada Siswa Kelas XII Program Keahlian Teknik Mesin Otomotif SMK Texmaco Pemalang. Jurnal PTM (Online). 9(1). (http://smapeunaron.pas.sch.id/, diakses 22 Januari 2015.

Sallis, E. (2006). Total Quality Management in Education. Jogjakarta: IRCiSoD.

Slameto. (2003). Belajar dan Faktor-faktor yang Mempengaruhinya. Jakarta: PT. Rineka Cipta.

Sobur, A. (2003). Psikologi Umum. Bandung: Pustaka Setia.

Supartono. (2004). Ilmu Budaya Dasar. Jakarta: Ghalia Indonesia. 
Undang-undang Republik Indonesia Nomor 20 tahun 2003 tentang Sistem Pendidikan Nasional. Jakarta: CV. Eko Jaya.

Yanti, P. E. D., I Made, N. \& I Ketut, D. (2014). Pengaruh Lingkungan Keluarga terhadap Berwirausaha Siswa Kelas XI SMK Negeri 1 Singaraja. Vol: 4 N0: 1 Tahun: 2014. Portalgaruda.org/ article.php?article=138903\&val=1355. Diakses tanggal 22 Januari 2015.

Yulianto, A. (2013). Pengaruh Prestasi Praktik Kerja Industri Terhadap Minat Berwirausaha Siswa. Gardan, Jurnal Ilmiah IKIP Veteran Semarang. Prodi Pendidikan Teknik Mesin, 3(2) Tahun 2013. 